\title{
Farklı Yulaf (Avena sativa L.) Çeşitlerinin Kimyasal Kalite Özellikleri
}

\author{
Zeki MUT $^{1 *}$, Özge Doğanay ERBAŞ KÖSE ${ }^{1}$, Hasan AKAY ${ }^{2}$ \\ ${ }^{1}$ Bozok Üniversitesi, Ziraat Fakültesi, Tarla Bitkileri Bölümü, Yozgat, Türkiye \\ ${ }^{2}$ Ondokuz Mayıs Üniversitesi, Ziraat Fakültesi, Tarla Bitkileri Bölümü, Samsun, Türkiye \\ *e-posta: zeki.mut@bozok.edu.tr
}

Özet: Yulaf insan yiyeceği ve hayvan yemi olarak kullanılan önemli bir tahıldır. Bu çalışmada dünyanın farklı yerlerinde yetiştirilmekte olan 81 yulaf çeşidinin üç çevredeki tane kimyasal içeriği araştırılmıştır. Çalışma 2007-2008 ve 2008-2009 yetiştirme sezonlarında Samsun-Kurupelit ve 2008-2009 yetiştirme sezonunda Bafra'da 9 X 9 alfa latis deneme desenine göre 3 tekrarlamalı olarak yürütülmüştür. Birleştirilmiş varyans analiz sonuçları incelenen tüm özelliklerin çeşitlere göre önemli oranda değiştiğini göstermiştir. Ayrıca, çeşit $\times$ çevre interaksiyonu tüm özellikler için önemli olmuştur. Çevrelerin ortalamasına göre; çeşitlerin protein oranı $\% 10.28$ ile 13.70 , yağ oranı $\% 3.10$ ile 6.37 , nişasta oranı $\%$ 33.45 ile 46.28 , $\beta$-glukan oranı \% 2.17 ile 3.40, ADF değeri \% 13.56 ile 18.54, NDF değeri $\% 31.35$ ile 37.57 , potasyum içeriği 3.95 ile $6.19 \mathrm{~g} / \mathrm{kg}$, magnezyum içeriği 1.20 ile $1.75 \mathrm{~g} / \mathrm{kg}$, fosfor içeriği 3.07 ile 4.32 $\mathrm{g} / \mathrm{kg}$ ve kalsiyum içeriği ise 0.30 ile $0.52 \mathrm{~g} / \mathrm{kg}$ arasında değişmiştir. Biplot grafiğine göre; Dal çeşidi, ADF ve NDF değerleri, Capa çeşidi $\mathrm{K}, \mathrm{Ca}, \mathrm{Mg}$ ve protein oranı, CROA 43 çeşidi $\mathrm{P}$ içeriği, Barra, Yeşilköy1779, Kermit, Faikbey ve Calibre-A çeşitleri $\beta$-glukan ve nişasta oranı bakımından ön plana çıan çeşitler olmuştur.

Anahtar kelimeler: $\beta$-glukan, Kalite, Protein, Yağ, Yulaf

\section{Chemical Quality Properties of Different Oat (Avena sativa L.) Cultivars}

\begin{abstract}
Oat is an important cereal as human food and animal feed. In this study, the chemical content of 81 oat cultivars grown in different country of the world was investigated at 3 environments. This study was carried out during the 2007-2008 and 2008-2009 growing seasons in Samsun-Kurupelit and Bafra environments, using a $9 \times 9$ alpha-lattice incomplete block design with three replicates. Analysis of the combined data showed significant genotypic differences for all investigated traits. Also, the cultivar $\times$ environment interaction was significant for all traits. According to the average of the environments, among the cultivars, protein content varied from 10.28 to $13.70 \%$, fat content from 3.10 to $6.37 \%$, starch content ranged from 33.45 to $46.28 \%$, $\beta$-glucan content from 2.17 to $3.40 \%$, ADF from 13.56 to $18.54 \%$, NDF from 31.35 to $37.57 \%$, K concentration from 3.95 to $6.19 \mathrm{~g} \mathrm{~kg}^{-1}, \mathrm{Mg}$ concentration from 1.20 to $1.75 \mathrm{~g} \mathrm{~kg}^{-}$ , $\mathrm{P}$ concentration from 3.07 to $4.32 \mathrm{~g} \mathrm{~kg}^{-1}$ and $\mathrm{Ca}$ concentration 0.30 to $0.52 \mathrm{~g} \mathrm{~kg}^{-1}$. According to Biplot graph; $\mathrm{ADF}$ and NDF values for Dal varieties; $\mathrm{K}, \mathrm{Ca}, \mathrm{Mg}$ and protein ratios for the capa variety; $\mathrm{P}$ content for CROA 43 varieties; $\beta$-glucan and starch ratiofor Barra, Yeşilköy-1779, Kermit, Faikbey and Caliber-A varieties were found in the foreground in terms of properties.
\end{abstract}

Keywords: $\beta$-glucan, Quality, Protein, Fat, Oat

\section{Giriş}

Yulaf 22.7 milyon ton üretimi ile Dünya'da üretilen buğday, mısır, çeltik, arpa ve sorgum gibi tahıl bitkilerinden sonra altıncı sırada yer almaktadır (FAO, 2014). Türkiye'de ise yulaf 99.3 bin hektar alanda ekilmekte ve 225 bin ton tane ürünü alınmaktadır (TÜİK, 2016). Yulaf, hayvan yemi, insan gıdası ile çeşitli endüstri ürünlerinin eldesin de kullanılan ve önemi günden güne artan önemli bir tahıldır (Marshall ve ark., 2013). Yulaf tanesi yaklaşık \%12.4-24.4 protein, \%3.0-11.0 yă̆ ve \%1.8-7.5 $\beta$-glukan içerir (Yaver ve Ertaş, 2013). Hayvan beslenmesinde yulaftan en yüksek verimi almak için, protein ve yağ oranının yüksek, $\beta$-glukan oranının ise düşük olması istenmektedir. Tanenin sindirilebilirliğine ve metabolik enerji içeriğgine katkıda bulunan kimyasal unsurlar nişasta, yağ ve hücre duvarındaki yapısal olan karbonhidratlardır (Campbell ve ark. 1992). Asit deterjanda çözünmeyen lif (ADF) bitki hücre duvarı yapısındaki selüloz, 
lignin ve çözünmeyen protein miktarını gösterir. Ayrıca yemin sindirilebilirliği ve hayvanın enerji alımı hakkında da bilgi veren iyi bir göstergedir. Yüksek ADF içeren yemlerin sindirilebilirliği ve enerji değeri düşüktür (Kutlu, 2008). Nötr deterjanda çözünmeyen lif (NDF) bitki hücre duvarı yapısında bulunan selüloz, hemiselüloz, lignin, kütin ve çözünmeyen protein miktarını ifade eder. NDF değeri hayvanların yem alımına doğrudan etkili olduğundan, yemde bu değer düştükçe hayvanın yem alımı artar (Van Soest ve ark. 1991).

Yulaf tanelerinin protein, yağ, vitamin, fosfor, demir, kalsiyum, magnezyum içeriği yüksek olması nedeniyle besleyici değeri yüksektir (Peterson ve ark. 2005). Son yıllarda, özellikle tüm tane ürünlerinin insan beslenmesindeki yerinin yeniden önem kazanmasından dolayı yulafın gıda olarak kullanımı tavsiye edilmektedir. Birçok vitamin ve mineral madde yulaf tanesi içerisinde kabuk ve embriyoda yer aldığından, gıdalara yulaf tüm tane olarak katılmaktadır. Yulaf, yüksek lif içeriği ve kalitesinden dolayı kolestrolü ve kan şekerini düşürdüğü bundan dolayı da insan beslenmesinde değerli bir gıdadır.

Türkiye'de yetiştirilen çeşitlerin çoğu genellikle tane kalitesinden çok tane verimi, hastalık, zararlılar ve çevresel strese toleransı göz önüne alınarak ıslah edilmiştir. Yulaf tanesinin kullanım amacını, hektolitre ağırlığı, bin tane ağırlığı, iç oranı gibi tanenin fiziksel özellikleri ile protein, yağ, nişasta ve beta glukan gibi kimyasal içerikleri belirler. Tüm bu özellikler genotip, çevre ve genotip-çevre interaksiyonu tarafindan belirlenir (Doehlert ve ark. 2001; Peterson ve ark. 2005).

$\mathrm{Bu}$ çalışma, farklı orijinli yulaf çeşitlerinin tanenin kimyasal içeriklerinin belirlenmesi ve 1slah çalışmalarında kullanılabilecek genotipleri belirlemek amacıyla Samsun-Kurupelit ve Bafra koşullarında yürütülmüştür.

\section{Materyal ve Yöntem}

Çalışmada, 26 ülkeden temin edilen 81 yulaf çeşidi materyal olarak kullanılmıştır (Çizelge 2). Çalışma 2007-2008 ve 2008-2009 yetiştirme sezonunda Ondokuz Mayıs Üniversitesi, Ziraat Fakültesinin Kurupelit Yerleşkesinde yer alan Tarla Bitkileri Araştırma ve Uygulama arazisinde $\left(41^{\circ} 21^{\prime} \mathrm{N}, 36^{\circ} 15^{\prime}\right.$ E ve yükseklik 195 m) ve 2008-2009 yetiştirme döneminde Samsun'un Bafra ilçesinde çiftçi arazisinde $\left(41^{\circ} 34^{\prime}\right.$ N, $35^{\circ} 55^{\prime}$ E ve yükseklik 74) yürütülmüştür.

Yetiştirme dönemindeki aylara göre yağış toplamı, ortalama sıcaklık ve nispi nem değerleri Çizelge 1'de verilmiştir. Denemin yürütüldüğü Ondokuz Mayıs Üniversitesi Ziraat Fakültesi araştırma ve uygulama arazisi toprakları her iki yılda da killi, Bafra'da ise killi-tınlı tekstüre sahiptir. Samsun merkezde ilk yıl toprakların pH'sı nötr (6.88), kireçsiz (\% 0.26), hafif tuzlu (\% 0.12), fosfor çok az (2.4 kg/da), potasyum fazla $(74 \mathrm{~kg} / \mathrm{da})$ ve organik madde orta $(\% 2.80)$ olup, ikinci yıl toprakların pH'sı hafif asit (6.30), kireçsiz $(\% 0.32)$, tuzsuz $(\% 0.07)$, fosfor az $(3.50 \mathrm{~kg} / \mathrm{da})$, potasyum fazla $(170 \mathrm{~kg} / \mathrm{da})$ ve organik madde orta $(\%$ 2.91) düzeydedir. Bafra'daki deneme topraklarının ise pH'sı nötr (6.95), kireçli (\% 8.8), tuzsuz (\% 0.09), fosfor az (4.9 kg/da), potasyum fazla $(70 \mathrm{~kg} / \mathrm{da})$ ve organik madde az $(\% 1.58)$ düzeydedir.

Ekim $\mathrm{m}^{2}$ ye 450 canlı tohum olacak şekilde 4 metre uzunluğundaki parsellere sıra arası $20 \mathrm{~cm}$ ve 6 sıra olarak Samsun-Kurupelit'de her iki yılda da Kasım ayının ilk haftasında, Bafra'da ise Kasım ayının ikinci haftasında yapılmıştır. Araştırma $9 \times 9$ alfa latis deneme desenine göre ve 3 tekrarlamalı olarak yürütülmüştür. Ekimle birlikte dekara $6 \mathrm{~kg}$ fosfor ve $6 \mathrm{~kg}$ azot olacak şekilde gübreleme yapılmıştır. Ayrıca kardeşlenme döneminde $6 \mathrm{~kg} / \mathrm{da}$ azotlu gübre üst gübresi olarak uygulanmıştır. Geniş yapraklı yabancı otlara karşı kardeşlenme döneminde herbisit (Tribenuran-metil (DF) \%75) kullanılmıştır. Hasat tüm denemelerde haziranın üçüncü haftası yapılmıştır. Harman edilen taneler laboratuvar analizlerinin yapılacağı döneme kadar soğuk hava deposunda muhafaza edilmiştir. Araştırmada tanenin protein, nişasta, yağ, $\beta$-glukan, ADF, NDF, K, Ca, P ve Mg içeriği belirlenmiştir. Kimyasal analizlerden protein analizi; Kjeldahl, yağ analizi; Soxhlet, nişasta; Ewers Polarimetrik ve $\beta$-glukan;enzimatik metodlara göre yapılmıştır (AOAC 984.13; AOAC 920.39; STN EN ISO 10520 2002;AACC 32-23, AACC 2000). ADF ve NDF değerleri Van Soest ve ark. (1991)'na göre, tanenin $\mathrm{K}, \mathrm{Ca}, \mathrm{Mg}$ içerikleri Atomik Absorbsiyon Spektroskopisi ile ve P içeriği ise "Olsen” yöntemine göre belirlenmiştir (Kacar 1994). 
Çizelge 1. Araştırmanın yürütüldüğü yerlere ait aylık ortalama sıcaklık, toplam yağış ve ortalama nispi nem değerleri *

\begin{tabular}{|c|c|c|c|c|c|c|c|c|c|c|c|}
\hline & & & Kasım & Aralık & Ocak & Şubat & Mart & Nisan & Mayıs & Haz. & Vej.Ort. \\
\hline \multirow{9}{*}{ 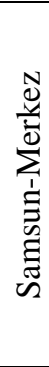 } & Ort. & $2007-08$ & 11.2 & 8.0 & 4.1 & 5.8 & 11.4 & 13.6 & 15.0 & 20.5 & 11.2 \\
\hline & Sicak. & 2008-09 & 13.3 & 9.0 & 8.4 & 9.0 & 8.4 & 9.7 & 15.8 & 21.9 & 11.9 \\
\hline & $\left({ }^{\circ} \mathrm{C}\right)$ & Uzun y. & 11.8 & 8.9 & 6.9 & 6.6 & 7.8 & 11.1 & 15.3 & 20.1 & 11.1 \\
\hline & & $2007-08$ & 96.5 & 69.4 & 42.7 & 67.9 & 36.8 & 48.0 & 40.7 & 35.8 & 437.8 \\
\hline & & 2008-09 & 109.5 & 120.7 & 86.1 & 91.0 & 49.0 & 21.4 & 55.3 & 8.2 & 541.2 \\
\hline & & Uzun y. & 81.8 & 73.4 & 59.7 & 50.3 & 56.8 & 58.4 & 51.0 & 47.8 & 479.2 \\
\hline & Nispi & $2007-08$ & 67.2 & 69.5 & 62.0 & 61.5 & 67.5 & 78.5 & 75.6 & 74.2 & 69.5 \\
\hline & Nem & 2008-09 & 75.6 & 59.8 & 59.2 & 71.4 & 74.8 & 79.9 & 78.3 & 76.0 & 71.9 \\
\hline & $(\%)$ & Uzun y. & 70.5 & 66.4 & 67.2 & 69.9 & 75.6 & 79.4 & 80.8 & 76.3 & 73.3 \\
\hline \multirow{6}{*}{$\begin{array}{l}\mathbb{T} \\
\stackrel{\tilde{E}}{\tilde{D}} \\
\end{array}$} & Ort. & $2008-09$ & 10.3 & 7.1 & 2.4 & 4.6 & 11.1 & 13.6 & 15.3 & 20.7 & 10.6 \\
\hline & Sicak. & Uzun y. & 12.1 & 9.4 & 7.3 & 7.4 & 9.2 & 12.2 & 15.8 & 20.6 & 11.8 \\
\hline & Yağ1ş & 2008-09 & 84.8 & 143.1 & 47.5 & 75.5 & 35.6 & 38.9 & 19.4 & 36.4 & 481.2 \\
\hline & $(\mathrm{mm})$ & Uzun y. & 88.7 & 91.6 & 98.5 & 76.3 & 69.5 & 47.9 & 41.5 & 40.4 & 554.4 \\
\hline & Nispi & 2008-09 & 75.4 & 76.7 & 70.7 & 70.2 & 71.8 & 79.6 & 76.6 & 72.1 & 74.1 \\
\hline & $\operatorname{Nem}(\%)$ & Uzun y. & 76.6 & 74.7 & 74.8 & 73.6 & 75.7 & 77.9 & 76.4 & 78.6 & 76.0 \\
\hline
\end{tabular}

* Samsun Meteoroloji Bölge Müdürlüğü kayıtları

Verilerin istatistiki analizi her yer ve yıl bir çevre olarak ele alınmış ve $9 \times 9$ alfa latis deneme desenine göre SAS (SAS 1990) istatistik programında yapılmış ve şu model uygulanmıştır: $x_{\mathrm{ijkl}}=\mu+t_{i}\left(e_{k}\right)+b_{j}\left(e_{k}\right)+e_{k}+$ $g_{l}+(\mathrm{ge})_{k l}+e_{i j k l}, x_{\mathrm{ijkl}}$ i eksik bloğunda j tekrarında k çevresindeki 1 genotipinin değeri, $\mu$ : genel ortalama, $t_{i}\left(e_{k}\right)$ : k çevresindeki i eksik bloğunun etkisi, $b_{j}\left(e_{k}\right)$ : k çevresindeki j tekrarının etkisi, $e_{k}$ : k çevresinin etkisi, $g_{l}: 1$ genotipin etkisi, $(\mathrm{ge})_{k l}: 1$ genotip ile k çevresinin interaksiyon etkisi, $e_{i j k l}$ :hata

Ortalamalar arasındaki farklılıklar, LSD çoklu karşılaştırma testine göre \% 5 önemlilik seviyesinde değerlendirilmiştir. Biplot analizi, Biplot Makro eklentisi (Lipkovich ve Smith 2002) ile Microsoft Excel programında yapılmıştır.

\section{Bulgular ve Tartışma}

Denemenin yürütüldüğü üç çevrenin aylık yağış, ortalama sıcaklık ve ortalama nispi nem değerleri Çizelge 1 'de verilmiştir. Samsun-Merkez'de toplam yağış miktarı denemenin yürütüldüğü birinci yılda (437.8 mm) uzun yıllar toplam yağış miktarından $(481.3 \mathrm{~mm})$ daha düşük, ikinci yılda ise $(541.2 \mathrm{~mm})$ daha yüksek olmuştur. Samsun-Bafra'da ise denemenin yürütüldüğü yılda $481.2 \mathrm{~mm}$ yağış düşmüş ve bu değer uzun yıllar ortalamasından (554.4 mm) daha az olmuştur (Çizelge 1).

Varyans analizi sonuçlarına göre incelenen tüm özellikler bakımından çeşitler ve çevreler arasındaki farklılığın önemli olduğu tespit edilmiştir (Çizelge 2). Ayrıca çeşit x çevre interaksiyonunun da çalışmada incelenen özellikler üzerine önemli etkiye sahip olduğu görülmüştür.

Çizelge 2. Yulaf çeşitlerinin kimyasal kalite özelliklerine ilişskin birleştirilmiş varyans analiz sonuçları (kareler ortalamas1)

\begin{tabular}{|c|c|c|c|c|c|c|c|c|c|c|c|}
\hline VK & SD & $\mathrm{PO}$ & YO & NO & $\beta G$ & $\mathrm{ADF}$ & $\mathrm{NDF}$ & K & $\mathrm{Mg}$ & $\mathrm{P}$ & $\mathrm{Ca}$ \\
\hline Çevre (Ç) & 2 & $530.4^{* *}$ & $52.5^{* * *}$ & $962.9 * *$ & $33.22 * *$ & $142.8^{* *}$ & $805.3^{* *}$ & $200.2^{* *}$ & $2.91 * *$ & $20.14 * *$ & $1.20 * *$ \\
\hline Tekrar & 6 & 1.04 & 0.33 & 23.3 & 0.7 & 2.1 & 5.6 & 0.15 & 0.010 & 0.003 & 0.002 \\
\hline Blok & 72 & 0.07 & 0.31 & 15.2 & 0.2 & 0.24 & 0.4 & 0.09 & 0.002 & 0.002 & 0.001 \\
\hline Çeşit (G) & 80 & $8.66^{* * *}$ & $5.60 * *$ & $189.4 * *$ & $15.3 * *$ & $17.9^{* *}$ & $59.1 * *$ & $47.2 * *$ & $0.099 * *$ & $2.41 * *$ & $0.32 * *$ \\
\hline GX Y & 160 & $2.37 * *$ & $0.65 *$ & $22.5^{*}$ & $1.19 * *$ & $4.46^{*}$ & $12.9^{*}$ & $1.21 * *$ & $0.031 * *$ & $0.11^{* *}$ & $0.009 * *$ \\
\hline Hata & 408 & 0.80 & 0.27 & 16.0 & 0.001 & 3.55 & 9.3 & 0.03 & 0.003 & 0.03 & 0.001 \\
\hline Genel & 728 & & & & & & & & & & \\
\hline VK $(\%)$ & & 7.5 & 4.4 & 9.7 & 1.1 & 12.4 & 8.9 & 3.2 & 3.6 & 4.4 & 4.8 \\
\hline
\end{tabular}

Çevrelerin birleştirilmiş varyans analiz sonucuna göre yulaf çeşitlerinin protein oranı \% 10.27 ile 13.69, yağ oranı \% 3.11 ile 6.37 , nişasta oranı \% 33.47 ile $46.27, \beta$-glukan oranı $\% 2.17$ ile 3.39 , ADF değeri \% 
13.57 ile 18.56, NDF değeri \% 31.33 ile 37.58, potasyum içeriği 3.95 ile $4.32 \mathrm{~g} / \mathrm{kg}$, magnezyum içeriği 1.20 ile $1.75 \mathrm{~g} / \mathrm{kg}$, fosfor içeriği 3.07 ile $4.32 \mathrm{~g} / \mathrm{kg}$ ve kalsiyum içeriği ise 0.30 ile $0.52 \mathrm{~g} / \mathrm{kg}$ arasında değişmiştir (Çizelge 3).

En yüksek yağ oranı, nişasta oranı ve $\beta$-glukan oranı Samsun-Kurupelit lokasyonunun da birinci yılda yürütülen denemede (sirasılla \% 5.20, \% 43.0 ve \% 3.13) elde edilirken, bunu Samsun-Bafra (sırasıyla \% 4.43, \% 41.77 ve \% 2.40) ve Samsun-Kurupelit (sırasiyla \% 4.36, \% 38.92 ve \% 2.81) lokasyonunda ikinci yılda yürütülen denemeler izlemiştir. En yüksek protein, ADF, NDF, potasyum, magnezyum, fosfor ve kalsiyum değerleri sirasıyla \% 13.53, \% 15.96, \% 36.42, \% 6.06, \% 1.63, \% 4.01 ve \% 0.46 ile SamsunKurupelit lokasyonununda ikinci yılda yürütülen denemede elde edilmiştir. Bu lokasyonu protein, ADF, NDF, potasyum, magnezyum, kalsiyum içerikleri bakımında Samsun-Bafra lokasyonu, fosfor içeriği bakımından ise Samsun-Kurupelit lokasyonun birinci yılında yapılan denemeden elde edilen sonuçlar izlemiştir (Çizelge 3).

Çizelge 3'de görüldüğü üzere, üç çevrenin ortalamasına göre tane protein oranı bakımından Capa (\% 13.70), CROA 43 (\% 13.57), Aarre (\% 13.49), Lvovskii Ranni (\% 13.41), Brawn (\% 13.19), Akiyutaka (\% 13.09), Auteuil (\% 13.02) ve CROA 11 (\% 12.96) çeşitleri en yüksek değere sahip olmuşlar ve istatistiki olarak aynı grupta yer almışlardır.

Protein miktarının önemli ölçüde genotipe bağlı olmasına karşın büyük ölçüde çevreden etkilendiği bildirilmektedir (Stone ve Savin, 1999). Doehlert ve ark. (2001) ise yaptıkları çalışmada, protein oranının, genetik ve çevresel faktörlerden eşit oranda etkilendiğini ortaya koymuşlardır. Yapılan çalışmalarda genotiplerin tane protein oranı \% 12.0 ile 17.6 (Erbaş ve Mut, 2013), \% 8.80 ile 14.80 (Dumlupınar ve ark., 2011), \% 12.6 ile 15.9 (Kahraman ve ark., 2012), \% 11.1 ile 14.3 (Mut ve ark., 2016), \%12.4-24.4 (Yaver ve Ertaş, 2013), \%13.7 ile 17.4 (Sarı ve ark., 2016), \% 10.76 ile 14.70 (Sabandüzen ve Akçura, 2017) arasında değişmiştir.

Yağının değerli yağ asidi kompozisyonu içermesinden dolayı yulaf yüksek besin değerine sahiptir (Zhou ve ark., 1999; Martinez ve ark., 2010). Yağ oranı bakımından Samsun-Kavak (\% 6.37), Yeşilköy-330 (\% 6.05), Faikbey (\% 6.00), Bursa (\% 5.98), Samsun-Bafra (\% 5.95) ve Flämingslord (\% 5.91) çeşitleri öne çıkan çeşitler olmuş ve istatistiki olarak aynı grupta oldukları tespit edilmiştir. Yulaf tanesi buğday, arpa ve çavdar tanelerinden daha fazla yağ içermekte ve yağ oranı genotip ve çevreye göre değişim göstermektedir (Saastamoinen ve ark., 1989). Yulaf tanesindeki yă̆ oranı genetik olarak kontrol edildiğinden, 1slahçılar insan yiyeceği olarak kullanılacak yulafların seçiminde düşük yağ oranına sahip genotipleri seçmektedirler (Zhou ve ark., 1999). Yapılan çalışmalarda yağ oranı \% 3.3 ile 7.5 (Erbaş ve Mut, 2013), 5.86 ile 8.47 (Mut ve ark., 2016), \% 4.6 ile 8.7 (Sarı ve ark., 2016) arasında değişmiştir. Yulaf tanesindeki yağ oranı genotip ve çevre faktörlerinden etkilenmektedir. Tane verimi için genotip-çevre interaksiyonu çok yüksek bulunurken, kalite özellikleri için (özellikle $\beta$-glukan ve yağ içerikleri için) genotip-çevre interaksiyonlarının daha düşük olduğu görülmüştür (Yan ve ark., 2016).

Nişasta içeriği bakımından \% 46.28 nişasta içeren Ardo çeşidi ile \% 42.57 arasında nişasta içeren Yeşilköy 1779 çeşidi arasında kalan 25 çeşit istatistiki olarak aynı grupta yer almıştır.

Yulafta nişasta içeriği ile ilgili daha önce yapılan çalışmalarda; nişasta içeriği 15 Arjantin yulaf çeşidinde \% 33.6 ile 41.5 (Martinez ve ark., 2010), İngiliz kavuzsuz ve kavuzlu yulaf çeşitlerinde \% 40.0 ile 58.0 (Givens ve ark., 2000), İzmir koşullarında yazlık olarak yetiştirilen yulaf çeşit ve hatlarında \% 40.9 ile 59.6 (Sarı ve ark., 2012) ve Yozgat koşullarında yapılan çalışmada \% 34.9 ile 47.7 (Mut ve ark., 2016) arasında değiştiği bildirilmiştir.

Yulaf tanesinde de dikkate değer oranda bulunan $\beta$-glukanın, insanlarda bağışıklık sistemini güçlendirdiği, kandaki kolestrol ve kan glukoz seviyelerini düşürdüğü belirlenmiştir (Tiwari ve Cummins, 2009; Tsikitis ve ark., 2004). Bu nedenle, insan ve hayvan beslenmesi için kullanılacak yulaf çeşitlerinde $\beta$-glukan içeriğinin yüksek olması istenmektedir. Bu çalışmada, Yeşilköy 1779 (\% 3.40), Yeşilköy 330 ( \% 3.38) ve Avesta (\% 3.28) çeşitlerinin $\beta$-glukan içerikleri daha yüksek olmuş ve istatistiki olarak aynı grupta yer almışlardır. Fin yulaf hatlarında $\beta$-glukan içeriğine yağış ve sıcaklığın etkilerinin değerlendirildiği bir çalışmada; kuru ve sıcak yıllarda belirlenen $\beta$-glukan içeriğinin, yağışlı ve soğuk yıllara kıyasla önemli seviyede daha yüksek olduğu tespit edilmiştir (Saastamoinen ve ark., 2004). Farklı yulaf çeşit ve hatları ile 
yapılan çalışmada $\beta$-glukan içeriğinin \% 2.1 ile 4.0 (Sarı ve ark., 2012), \%1.33 ile 2.58 (Mut ve ark., 2016), $\% 1.1$ ile 2.6 (Sarı ve ark., 2016) arasında değiştiği bildirilmiştir.

Çizelge 3. Denemede yer alan yulaf çeşitlerinin kimyasal kalite özelliklerine ait ortalama değerler

\begin{tabular}{|c|c|c|c|c|c|c|c|c|c|c|c|}
\hline Çeşit Adı & Orijin & $\begin{array}{l}\mathrm{PO} \\
(\%)\end{array}$ & $\begin{array}{l}\mathrm{YO} \\
(\%)\end{array}$ & $\begin{array}{l}\text { NO } \\
(\%)\end{array}$ & $\begin{array}{l}\beta G \\
(\%)\end{array}$ & $\begin{array}{c}\text { ADF } \\
(\%)\end{array}$ & $\begin{array}{c}\text { NDF } \\
(\%)\end{array}$ & $\begin{array}{c}\mathrm{K} \\
\mathrm{g} \mathrm{kg}^{-1} \\
\end{array}$ & $\begin{array}{c}\mathrm{Mg} \\
\mathrm{g} \mathrm{kg}^{-1}\end{array}$ & $\begin{array}{c}\mathrm{P} \\
\mathrm{g} \mathrm{kg}^{-1}\end{array}$ & $\begin{array}{c}\mathrm{Ca} \\
\mathrm{g} \mathrm{kg}^{-1}\end{array}$ \\
\hline Blaze & US & 12.34 & 5.34 & 40.33 & 2.34 & 15.71 & 33.63 & 4.55 & 1.63 & 3.88 & 0.36 \\
\hline Expo & AT & 10.91 & 4.14 & 41.78 & 3.03 & 15.48 & 35.31 & 4.91 & 1.35 & 3.44 & 0.36 \\
\hline TAM 301 & US & 11.30 & 4.66 & 40.79 & 2.68 & 14.91 & 34.35 & 4.73 & 1.41 & 3.58 & 0.36 \\
\hline Neklan & $\mathrm{CZ}$ & 12.23 & 3.86 & 43.85 & 2.74 & 13.56 & 32.68 & 5.59 & 1.50 & 3.72 & 0.47 \\
\hline H'daka & JP & 12.90 & 3.10 & 41.25 & 2.85 & 14.93 & 35.16 & 6.19 & 1.55 & 3.64 & 0.52 \\
\hline Expander & AT & 11.28 & 4.47 & 44.90 & 2.91 & 15.24 & 35.08 & 4.60 & 1.38 & 3.49 & 0.36 \\
\hline Avesta & FR & 11.49 & 4.22 & 40.42 & 3.28 & 15.16 & 34.56 & 4.39 & 1.47 & 3.73 & 0.34 \\
\hline Sinelnikovski 1321 & UA & 11.22 & 4.95 & 36.08 & 2.52 & 16.35 & 35.78 & 4.94 & 1.49 & 3.66 & 0.38 \\
\hline Kwant & PL & 11.92 & 5.72 & 37.94 & 2.84 & 16.88 & 35.72 & 4.96 & 1.62 & 3.70 & 0.40 \\
\hline Charlton & $\mathrm{NZ}$ & 12.84 & 5.14 & 38.46 & 3.17 & 14.89 & 33.62 & 5.12 & 1.58 & 3.86 & 0.40 \\
\hline Revisor & $\mathrm{DE}$ & 11.33 & 3.68 & 40.07 & 2.74 & 15.23 & 35.19 & 4.80 & 1.36 & 3.32 & 0.41 \\
\hline Centennial & US & 12.00 & 4.09 & 44.08 & 3.27 & 14.88 & 34.21 & 5.34 & 1.49 & 3.69 & 0.44 \\
\hline Milton & US & 11.84 & 5.45 & 40.42 & 2.40 & 15.37 & 33.33 & 4.36 & 1.58 & 3.80 & 0.37 \\
\hline Bajka & PL & 11.49 & 3.99 & 43.00 & 2.79 & 14.21 & 33.80 & 5.14 & 1.42 & 3.54 & 0.42 \\
\hline Zvolen & SK & 12.06 & 3.34 & 38.99 & 2.82 & 14.90 & 35.57 & 5.67 & 1.50 & 3.64 & 0.46 \\
\hline Kermit & DE & 11.79 & 4.10 & 44.70 & 2.86 & 14.05 & 32.89 & 5.17 & 1.43 & 3.60 & 0.40 \\
\hline Event & AT & 11.02 & 4.03 & 40.96 & 2.62 & 14.35 & 33.39 & 5.05 & 1.37 & 3.45 & 0.39 \\
\hline Borowiak & PL & 12.16 & 4.90 & 39.79 & 2.76 & 15.35 & 34.09 & 5.46 & 1.55 & 3.75 & 0.41 \\
\hline Urano & CL & 12.04 & 5.14 & 43.83 & 2.90 & 14.61 & 32.97 & 4.79 & 1.48 & 3.55 & 0.37 \\
\hline Puhti & FI & 12.33 & 4.49 & 40.31 & 2.80 & 15.50 & 35.29 & 5.01 & 1.49 & 3.52 & 0.40 \\
\hline Auteuil & FR & 13.02 & 4.62 & 40.47 & 3.15 & 15.17 & 34.16 & 5.47 & 1.61 & 3.92 & 0.45 \\
\hline Fla"mingslord & DE & 12.33 & 5.91 & 41.97 & 2.68 & 15.85 & 33.84 & 4.70 & 1.58 & 3.73 & 0.36 \\
\hline CROA 43 & NZ & 13.57 & 3.88 & 43.62 & 3.03 & 14.08 & 33.25 & 6.02 & 1.59 & 3.81 & 0.50 \\
\hline Lvovskii Rannii & UA & 13.41 & 5.59 & 39.30 & 2.86 & 14.74 & 33.61 & 5.14 & 1.71 & 4.21 & 0.42 \\
\hline Katri & FI & 12.77 & 4.57 & 43.00 & 2.57 & 15.50 & 35.03 & 5.70 & 1.60 & 3.82 & 0.45 \\
\hline Sanova & DE & 12.63 & 3.70 & 43.65 & 2.78 & 14.24 & 34.24 & 5.74 & 1.51 & 3.67 & 0.46 \\
\hline Litoral & $\mathrm{BO}$ & 12.43 & 4.08 & 42.01 & 2.77 & 14.05 & 34.02 & 5.02 & 1.53 & 3.69 & 0.41 \\
\hline Capa & UY & 13.70 & 4.97 & 40.64 & 2.93 & 16.02 & 35.20 & 6.09 & 1.75 & 4.03 & 0.52 \\
\hline Dal & US & 11.52 & 5.35 & 33.45 & 2.75 & 18.54 & 37.57 & 5.28 & 1.57 & 3.59 & 0.41 \\
\hline Kolpashevskii & RU & 11.47 & 3.92 & 42.35 & 2.93 & 16.19 & 35.57 & 5.06 & 1.40 & 3.45 & 0.42 \\
\hline Aberglen & GB & 11.27 & 4.30 & 42.53 & 2.83 & 14.78 & 34.33 & 4.27 & 1.40 & 3.45 & 0.31 \\
\hline Skakun & RU & 10.95 & 4.89 & 38.17 & 2.19 & 15.37 & 33.98 & 4.50 & 1.42 & 3.46 & 0.35 \\
\hline Calibre B & $\mathrm{CA}$ & 11.30 & 4.86 & 44.16 & 2.85 & 14.76 & 33.63 & 4.18 & 1.38 & 3.47 & 0.33 \\
\hline Chantilly & FR & 11.50 & 5.71 & 37.71 & 2.62 & 16.97 & 35.37 & 4.72 & 1.58 & 3.72 & 0.36 \\
\hline Longchamp & FR & 11.24 & 4.05 & 40.72 & 2.91 & 15.40 & 35.15 & 4.93 & 1.42 & 3.51 & 0.36 \\
\hline Aarre & FI & 13.49 & 4.34 & 39.55 & 3.11 & 14.33 & 34.98 & 5.51 & 1.62 & 3.92 & 0.43 \\
\hline Barra & SE & 11.70 & 3.99 & 41.41 & 2.82 & 13.56 & 32.56 & 4.65 & 1.44 & 3.59 & 0.39 \\
\hline Chernigovskij 27 B & UA & 10.97 & 4.69 & 41.16 & 2.64 & 15.40 & 34.67 & 4.18 & 1.40 & 3.51 & 0.33 \\
\hline Winston & DE & 10.28 & 3.85 & 43.45 & 2.83 & 15.20 & 34.88 & 4.14 & 1.20 & 3.07 & 0.32 \\
\hline Irtysh 13 & RU & 10.81 & 5.14 & 41.31 & 2.82 & 16.89 & 35.24 & 4.59 & 1.41 & 3.29 & 0.35 \\
\hline Mara & LV & 12.26 & 5.35 & 39.04 & 2.59 & 15.55 & 34.38 & 4.90 & 1.59 & 3.85 & 0.38 \\
\hline Calibre A & $\mathrm{CA}$ & 11.58 & 5.05 & 44.42 & 2.85 & 14.12 & 32.54 & 5.12 & 1.44 & 3.65 & 0.41 \\
\hline Ardo & $\mathrm{CZ}$ & 10.33 & 4.00 & 46.28 & 2.76 & 14.49 & 33.95 & 4.33 & 1.33 & 3.30 & 0.33 \\
\hline Flipper & DE & 10.80 & 4.01 & 40.55 & 2.76 & 13.61 & 33.22 & 4.55 & 1.34 & 3.35 & 0.36 \\
\hline Evita & DE & 10.68 & 4.25 & 38.29 & 2.53 & 16.78 & 35.84 & 4.44 & 1.32 & 3.20 & 0.33 \\
\hline Ogle & US & 12.10 & 4.69 & 42.06 & 2.55 & 16.46 & 34.71 & 5.24 & 1.54 & 3.83 & 0.45 \\
\hline Belinda & SE & 11.73 & 5.39 & 41.89 & 2.91 & 15.82 & 34.54 & 4.97 & 1.54 & 3.77 & 0.38 \\
\hline Bakonyalja & $\mathrm{HU}$ & 12.48 & 4.12 & 39.63 & 2.65 & 13.87 & 33.62 & 5.44 & 1.51 & 3.68 & 0.43 \\
\hline CROA 11 & NZ & 12.96 & 4.51 & 44.13 & 2.72 & 14.32 & 33.15 & 5.62 & 1.57 & 3.76 & 0.46 \\
\hline Freja & SE & 11.31 & 5.16 & 35.62 & 2.85 & 16.77 & 36.19 & 4.74 & 1.48 & 3.55 & 0.34 \\
\hline Matra & NL & 11.69 & 3.91 & 46.13 & 2.38 & 14.03 & 33.14 & 5.53 & 1.51 & 3.72 & 0.45 \\
\hline Gerkules & RU & 12.12 & 4.96 & 40.93 & 2.60 & 14.86 & 34.40 & 5.27 & 1.51 & 3.71 & 0.41 \\
\hline IA93227-1 & US & 11.63 & 4.20 & 42.48 & 2.41 & 15.98 & 34.21 & 5.18 & 1.49 & 3.67 & 0.42 \\
\hline Brawn & US & 13.19 & 4.57 & 42.58 & 2.66 & 15.25 & 33.72 & 5.51 & 1.71 & 4.00 & 0.46 \\
\hline CDC Packer & $\mathrm{CA}$ & 12.17 & 4.13 & 42.77 & 2.58 & 15.05 & 34.25 & 5.61 & 1.51 & 3.57 & 0.45 \\
\hline Virma & FI & 12.76 & 4.61 & 41.57 & 2.48 & 15.06 & 34.34 & 6.12 & 1.61 & 3.90 & 0.49 \\
\hline Akiyutaka & JP & 13.09 & 4.93 & 40.83 & 2.17 & 16.50 & 35.06 & 5.30 & 1.71 & 3.87 & 0.46 \\
\hline Mantaro 15 & PE & 12.08 & 5.04 & 38.06 & 2.31 & 16.46 & 35.54 & 5.33 & 1.58 & 3.64 & 0.44 \\
\hline
\end{tabular}


Çizelge 3. Denemede yer alan yulaf çeşitlerinin kimyasal kalite özelliklerine ait ortalama değerler (devami)

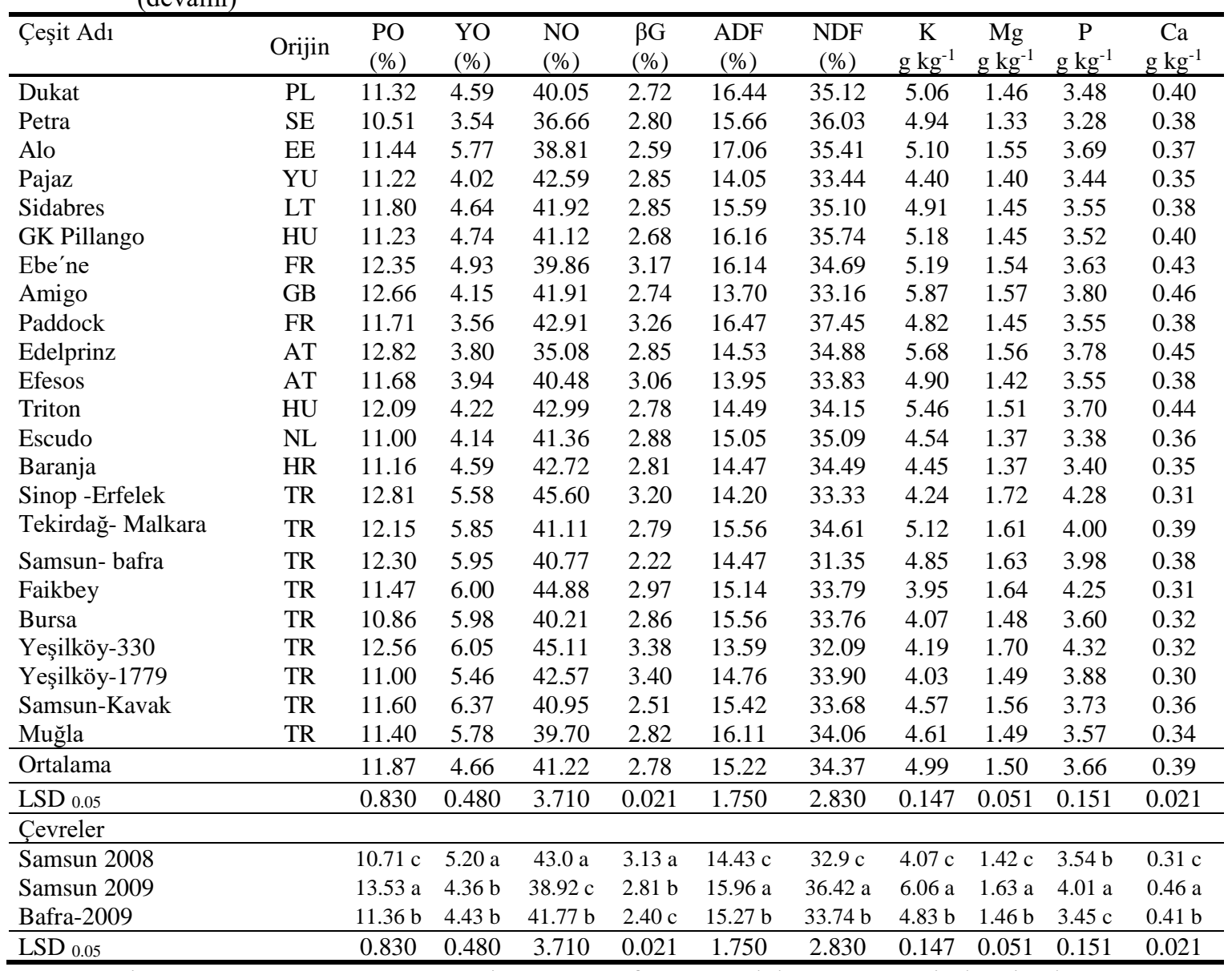

PO: Protein oran1, YO: Yağ oranı, NO: Nişasta oranı, $\beta$ G: Beta glukan, ADF, Asit deterjanda çözünmeyen lif, NDF: Nötr deterjanda çözünmeyen lif, K: potasyum, Mg: magnezyum, P: Fosfor: Ca: Kalsiyum

Yüksek ADF içeren yemlerin sindirilebilirliği ve enerji değeri düşük olmaktadır (Kutlu, 2008). ADF değeri bakımından Dal (\% 18.54), Alo (\% 17.06), Chantilly (\% 16.97), İrtysh 13 (\% 16.89) ve Kwant (\% 16.88) yüksek içeriğe sahip olmuşlar ve istatistiki olarak aynı grupta yer almışlardır. Barra (\% 13.56), Neklan (\% 13.56), Yeşilköy 330 (\% 13.59) ve Flipper (\% 13.61) çeşitleri ise en düşük ADF değerine sahip olmuş ve istatistiki olarak aynı grupta yer almışlardır (Çizelge 3). Nötr deterjanda çözünmeyen lif (NDF) bitki hücre duvarı yapısında bulunan selüloz, hemiselüloz, lignin, kütin ve çözünmeyen protein miktarını ifade eder. NDF değeri hayvanların yem alımına doğrudan etkili olduğundan, yemde bu değer düştükçe hayvanın yem alımı artar (Van Soest ve ark., 1991). Çalışmada, \% 34.88 (Winston) ile \% 37.57 (Dal) değerleri arasında NDF değerine sahip çeşitler en yüksek NDF oranına sahip olmuş ve istatistiki olarak aynı grupta yer almıştır. En düşük NDF değeri ise \% 31.35 ile Samsun-Bafra çeşidinde elde edilmiştir. Martinez ve ark. (2010) 18 yulaf çeşidi ile yaptıkları çalışmada ADF ve NDF değerlerinin çeşitlere göre istatistiki olarak önemli seviyede farklı olduğunu, ADF değerinin \% 14.27 ile 17.38, NDF değerinin ise \% 32.11 ile 38.44 arasında değiştiğini bildirmişlerdir. Rodehutscord ve ark. (2016) yulaf çeşitlerinde ADF değerinin \% 11.1 ile 16.7, NDF değerinin ise \% 26.1 ile 34.1 arasında değiştiğini, Kliševičiūtè ve ark. (2016) ise çeşitlere göre ADF değerinin \% 8.04 ile 17.19 ve NDF değerinin \% 24.11 ile 32.01 arasında değiştiğini bildirmişlerdir.

Potasyum içeriği bakımından H'daka $\left(6.19 \mathrm{~g} \mathrm{~kg}^{-1}\right)$, Virma $\left(6.12 \mathrm{~g} \mathrm{~kg}^{-1}\right)$ ve Capa $\left(6.09 \mathrm{~g} \mathrm{~kg}^{-1}\right)$ çeşitleri en yüksek değere sahip olmuşlar ve istatistiki olarak aynı grupta yer almışlardır. Faikbey $\left(3.95 \mathrm{~g} \mathrm{~kg}^{-1}\right)$, Yeşilköy 1779 (4.03 $\mathrm{g} \mathrm{kg}^{-1}$ ) ve Bursa $\left(4.07 \mathrm{~g} \mathrm{~kg}^{-1}\right.$ ) çeşitlerinin ise tane potasyum içeriği en düşük seviyede olmuştur. Capa (1.75 $\left.\mathrm{g} \mathrm{kg}^{-1}\right)$, Sinop-Erfelek $\left(1.72 \mathrm{~g} \mathrm{~kg}^{-1}\right)$, Lvoskii Ranni $\left(1.71 \mathrm{~g} \mathrm{~kg}^{-1}\right)$, Brawn $\left(1.71 \mathrm{~g} \mathrm{~kg}^{-1}\right)$ ve Yeşilköy $330\left(1.70 \mathrm{~g} \mathrm{~kg}^{-1}\right)$ çeşitleri magnezyum içeriği en yüksek çeşitler olarak tespit edilmiş ve istatistikî olarak aynı grupta yer almışlardır. Winston $\left(1.20 \mathrm{~g} \mathrm{~kg}^{-1}\right)$, Evita $\left(1.32 \mathrm{~g} \mathrm{~kg}^{-1}\right)$, Petra $\left(1.33 \mathrm{~g} \mathrm{~kg}^{-1}\right) \mathrm{ve}$ 
Ardo (1.33 $\left.\mathrm{g} \mathrm{kg}^{-1}\right)$ çeşitleri ise en düşük miktarda magnezyum içeriğine sahip olmuşlardır. Yüksek tane fosfor içeriği bakımından Yeşilköy 330 (4.32 $\mathrm{g} \mathrm{kg}^{-1}$ ), Sinop-Erfelek $\left(4.28 \mathrm{~g} \mathrm{~kg}^{-1}\right)$, Faikbey $\left(4.25 \mathrm{~g} \mathrm{~kg}^{-1}\right) \mathrm{ve}$ Lvovskii Rannii (4.21 g kg$)$ çeşitleri öne çıkan çeşitler olmuştur. Winston $\left(3.07 \mathrm{~g} \mathrm{~kg}^{-1}\right)$ ve Evita $(\% 3.20 \mathrm{~g}$ $\mathrm{kg}^{-1}$ ) çeşitleri ise çalışmada en düşük fosfor içeriğine sahip çeşitler olarak belirlenmiştir. Üç çevrenin ortalamasına göre çeşitlerin tane kalsiyum içerikleri $0.30 \mathrm{~g} \mathrm{~kg}^{-1}$ (Yeşilköy-1779) ile $0.52 \mathrm{~g} \mathrm{~kg}^{-1}$ (H'daka ve Capa) arasında değişmiş olup, en yüksek kalsiyum içeriklerine sahip H'daka ve Capa $\left(0.52 \mathrm{~g} \mathrm{~kg}^{-1}\right)$ çeşitleri istatistiki olarak diğer çeşitlerden farklı grupta yer almışlardır (Çizelge 3). Çalışmada belirlenen elementlerin miktarı ile ilgili sonuçlar daha önce farklı araştırıcılar tarafından bildirilen bulgulara benzer olmuştur (McKechnie, 1983; Boila ve ark. 1993; Özcan ve ark. 2006; Kara ve ark. 2012).

\section{Özellikler arası ilişkiler ve Biplot analizi}

Genotip ve incelenen özellikler arasındaki ilişkileri bir bütün olarak gösteren biblot analizi, yalnızca iki özellik arasındaki ilişkiyi gösteren korelasyon analizine göre üstünlükleri vardır (Yan ve Reid, 2008). Bu çalışmada Biplot analizi \% 35.4'ünü Ana Bileşen 1 ve \% 23.3'ünü Ana Bileşen 2 olmak üzere toplamda varyasyonun \% 58.7'sini açıklamıştır (Şekil 1). Şekil 1 incelendiğinde ele alınan kalite özellikleri bakımından hangi çeşit ve çeşitlerin daha yüksek değerlere sahip olduğu, bu özelliklerin birbirleri ile olumlu veya olumsuz ilişkide olduğu görülebilmektedir. Biplot grafiğine göre ADF ile NDF, protein ile K, $\mathrm{P}, \mathrm{Ca}$ ve $\mathrm{Mg}$ ve kısmen yağ, nişasta ile de $\beta$-glukan özellikleri aynı yönde yer almıştır. Bu özelliklerin birbirleriyle olumlu ilişkide oldukları, söz konusu bölgenin köşegenlerinde yer alan çeşitlerinde bu özellikler bakımından öne çıkan çeşitler olduğu görülmüştür. Merkeze doğru yaklaşan çeşitler birden fazla özellik açısından öne çıkarken, genel ortalama değerleri bir özellik açısından öne çıkan çeşitlere göre daha düşük olmuştur (Şekil 1).

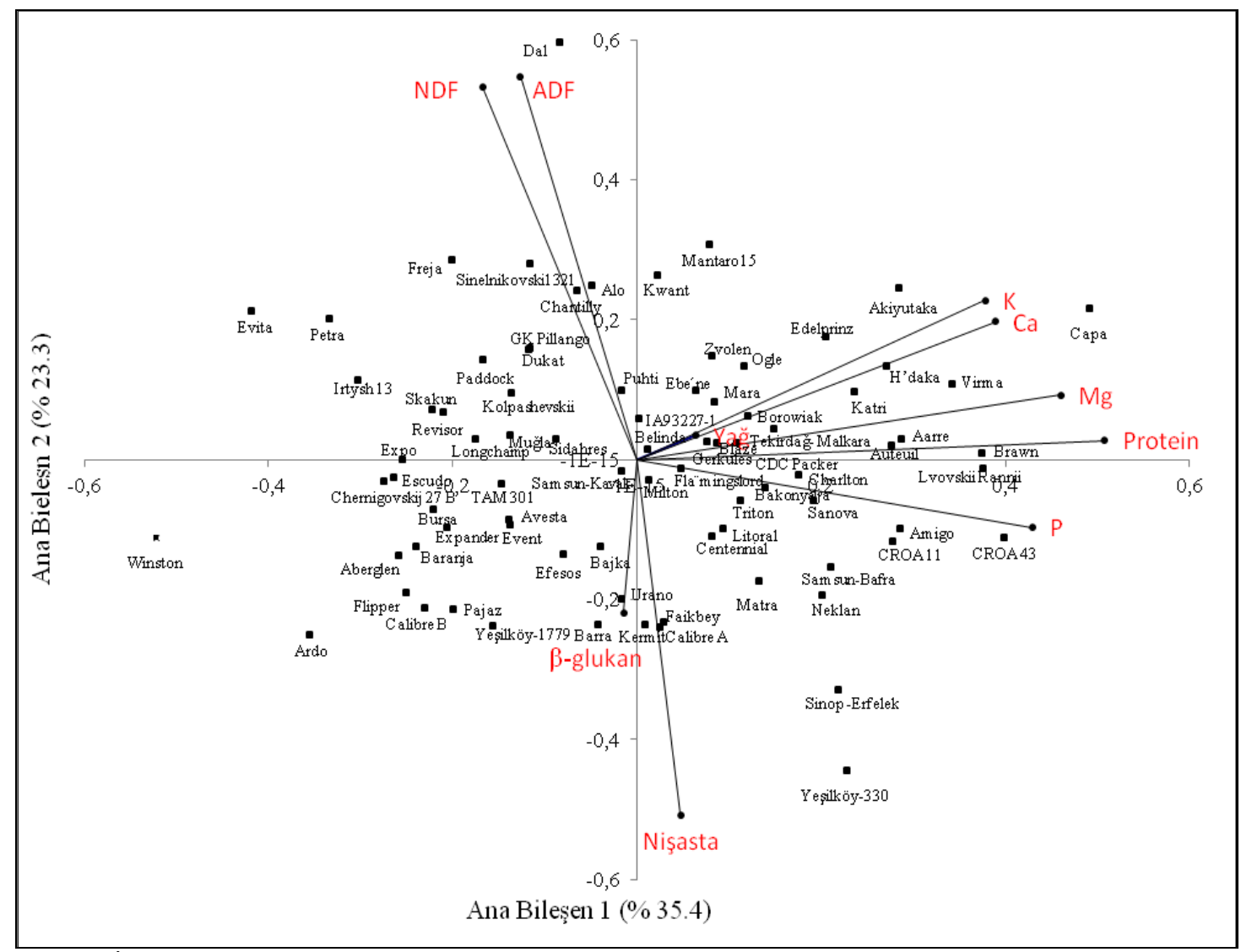

Şekil 1. İncelenen özelliklerin Biplot analiz yöntemi ile gruplandırılması ve çeşitlerin incelenen özelliklerle olan ilişkisi.

Araştırmada incelenen kalite özellikleri arasındaki ilişkiler Çizelge 4'de verilmiştir. Çizelge 4 incelendiğinde protein oranı ile $\mathrm{K}, \mathrm{Mg}, \mathrm{P}$ ve $\mathrm{Ca}$ değerleri arasında olumlu ve \%1 ihtimal seviyesinde önemli, protein oranı ile NDF oranı arasında ise olumsuz ve $\% 5$ ihtimal seviyesinde önemli ilişki 
belirlenmiştir. Protein oranı ile ADF oranı arasında istatistiki olarak önemsiz olmakla birlikte olumsuz, yağ, nişasta ve $\beta$-glukan oranları arasında ise olumlu bir ilişkinin olduğu görülmektedir. (Çizelge 4). Yulaf tanesinde yağ oranı ile protein içeriği arasında tutarlı bir ilişki bulunmamaktadır. Daha önce yapılan farklı yerlerdeki çalışmalarda pozitif ve negatif korelasyonların ortaya çıktığı yada önemli seviyede bir korelasyonun bulunmadığ1 bildirilmiştir (Peterson ve ark., 2005; Silva ve ark., 2008; Martinez ve ark., 2010; Mut ve ark., 2016). Martinez ve ark. (2010) protein oranı ile NDF içeriği arasında olumsuz bir ilişkinin olduğunu tespit etmişlerdir. $\beta$-glukan içeriğinin protein oranı ile olumlu ve önemsiz ilişki gösterdiği belirlenmiştir (Brunner ve Freed, 1994). $\beta$-glukan içeriği ile yağ oranı arasında olumsuz yönde önemli korelasyonların olduğu saptanmıştır (Kibite ve Edney, 1998; Mut ve ark., 2016). Ancak Peterson ve ark. (2005) $\beta$-glukan içeriği ile yağ oranı arasında istatistikî olarak önemsiz olmakla birlikte olumlu yönde korelasyonun olduğunu bildirmişlerdir.

Çizelge 4. Özellikler arası korelasyon katsayıları ve önemlilik seviyeleri

\begin{tabular}{|c|c|c|c|c|c|c|c|c|c|}
\hline & Protein & Yağ & Nişasta & B-glukan & $\mathrm{ADF}$ & $\mathrm{NDF}$ & K & MG & $\mathrm{P}$ \\
\hline Yă̆ & 0.067 & & & & & & & & \\
\hline Nişasta & 0.037 & -0.153 & & & & & & & \\
\hline$\beta$-glukan & 0.059 & -0.103 & $0.214^{*}$ & & & & & & \\
\hline $\mathrm{ADF}$ & -0.203 & $0.351 * *$ & $-0.549 * *$ & $-0.215^{* *}$ & & & & & \\
\hline $\mathrm{NDF}$ & $-0.219 *$ & -0.159 & $-0.521 * *$ & -0.037 & $0.764 * *$ & & & & \\
\hline K & $0.669 * *$ & $-0.372 * *$ & -0.097 & $-0.142 *$ & 0.062 & 0.090 & & & \\
\hline MG & $0.826 * *$ & $0.505^{* *}$ & -0.083 & -0.048 & 0.076 & $-0.173 * *$ & $0.390 * *$ & & \\
\hline $\mathrm{P}$ & $0.734 * *$ & $0.495 * *$ & 0.105 & 0.121 & -0.152 & $-0.352 * *$ & $0.230 * *$ & $0.914 * *$ & \\
\hline $\mathrm{Ca}$ & $0.695 * *$ & $-0.394 * *$ & -0.030 & $-0.169 *$ & 0.095 & 0.032 & $0.957 * *$ & $0.408 * *$ & $0.244 * *$ \\
\hline
\end{tabular}

Protein: Protein Oranı (\%), Yağ: Yağ Oranı (\%), Nişasta: Nişasta İçeriği (\%), ADF: Asit Deterjanda Çözünmeyen Lif (\%), NDF: Nötr Deterjanda Çözünmeyen Lif (\%), K: Potasyum (\%), Mg: Magnezyum $(\%)$, P: Fosfor (\%), Ca: Kalsiyum (\%)

Yağ oranı ile ADF, Mg ve P içerikleri arasında olumlu ve \%1 ihtimal seviyesinde önemli, ADF, K ve Ca içeriği arasında ise olumsuz ve \%1 ihtimal seviyesinde önemli ilişkinin olduğu belirlenmiştir. Nişasta oranı ile ADF ve NDF değerleri arasında \%1 ihtimal seviyesinde önemli ve olumsuz ilişki olduğu tespit edilmiştir (Çizelge 4). 25 farklı yulaf genotip ile yapılan çalışmada protein içeriği ile ADF oranı arasında istatistiki olarak önemsiz olmakla birlikte olumsuz bir ilişki, nişasta oranı ile ADF ve NDF değerleri arasında ise çok önemli ve olumsuz ilişkinin olduğu tespit edilmiştir (Mut ve ark., 2016). $\beta$-glukan oranı ile ADF değeri arasında \%1 ihtimal seviyesinde önemli ve olumsuz, $\mathrm{K}$ ve Ca içerikleri ile ise \% 5 ihtimal seviyesinde önemli ve olumsuz ilişki olduğu belirlenmiştir. ADF ile NDF değeri arasında \% 1 seviyesinde önemli ve olumlu ilişki olduğu belirlenmiştir. NDF değeri ile $\mathrm{K}$ ve $\mathrm{P}$ içerikleri arasında \% 1 ihtimal seviyesinde önemli ve olumlu ilişki olduğu tespit edilmiştir. Çalışmada incelenen bütün elementlerin birbirleriyle olan ilişkisi \%1 ihtimal seviyesinde önemli ve olumlu olarak tespit edilmiştir.

\section{Sonuç}

26 ülkeden temin edilen 81 yulaf çeşidinin kimyasal kalite özelliklerinin belirlenmesi amacıyla yapılan bu çalışmada; çeşitler ve çevreler arasındaki farklılığın önemli olduğu tespit edilmiştir. Ayrıca çeşit x çevre interaksiyonununda çalışmada incelenen özellikler üzerine önemli etkiye sahip olduğu görülmüştür. Çevrelerin birleştirilmiş varyans analiz sonucuna göre yulaf çeşitlerinin protein oranı \% 10.28 ile 13.70, yağ oranı $\% 3.10$ ile 6.37 , nişasta oranı \% 33.45 ile 46.28 , $\beta$-glukan oranı $\% 2.17$ ile 3.40 , ADF değeri \% 13.56 ile 18.54, NDF değeri \% 31.35 ile 37.57, potasyum içeriği 3.95 ile $6.19 \mathrm{~g} / \mathrm{kg}$, magnezyum içeriği 1.20 ile $1.75 \mathrm{~g} / \mathrm{kg}$, fosfor içeriği 3.07 ile $4.32 \mathrm{~g} / \mathrm{kg}$ ve kalsiyum içeriği ise 0.30 ile $0.52 \mathrm{~g} / \mathrm{kg}$ arasında değişmiştir.

Biplot grafiğine göre ADF ile NDF, protein ile $\mathrm{K}, \mathrm{P}, \mathrm{Ca}$ ve $\mathrm{Mg}$ ve kısmen yă̆, nişasta ile de $\beta$-glukan özellikleri aynı yönde yer almış ve bu özelliklerin birbirleriyle olumlu ilişkide oldukları tespit edilmiştir. Dal çeşidi, ADF ve NDF değerleri, Capa çeşidi $\mathrm{K}, \mathrm{Ca}, \mathrm{Mg}$ ve protein oranı, CROA 43 çeşidi P içeriği, Barra, Yeşilköy-1779, Kermit, Faikbey ve Calibre-A çeşitleri $\beta$-glukan ve nişasta oranı bakımından ön 
plana çıkan çeşitler olmuştur. Çalışmada kullanılan çeşitlerin kimyasal kalite özelliklerinin ve bu özelliklerin birbirleri ile olan ilişkilerinin belirlenmiş olması ıslah çalışmalarında bu çeşit ve özelliklerden yararlanılabileceğini göstermiştir.

\section{Kaynaklar}

AACC (2005). American Association of Cereal Chemists. Approved Methods of the AACC (11th ed.). St. Paul, USA.

AOAC (2012). Official methods of analysis (19th ed.). Association of Official Chemists. Washington D.C., USA.

Boila R J, Campbell L D, Stothers S C, Crow G H, Ibrahim E A (1993). Variation in the mineral content of cereal grains grown at selected locations throughout Manitoba. Canadian Journal of Animal Science, 73(2): 421-429.

Brunner B R, R D Freed (1994). Oat grain $\beta$-glucan content as affected by nitrogen level, location, and year. Crop Sci. 34:473-476.

Campbell C P, Marshall S A, Mandell I B, Wilton W J (1992). Effects of source of dietary neutral detergent fiber on chewing behavior in beef cattle fed pelleted concentrates with or without supplemental roughage. J. Anim Sci., 70, 894- 903.

Doehlert D C, McMullen M S, Hammond J J (2001). Genotypic and environmental effects on grain yield and quality of oat grown in North Dakota. Crop Science 41: 1066-1072.

Dumlupınar Z, Maral H, Kara R, Dokuyucu T, Akkaya A (2011). Evaluation of Turkish oat landraces based on grain yield, yield components and some quality traits. Turkish Journal of Field Crops, 16 (2): 190-196.

Erbaş Ö D, Mut Z (2013). Saf hat yulaf genotiplerinin tarımsal ve bazı kalite özelliklerinin belirlenmesi. X. Tarla Bitkileri Kongresi, 10-13 Eylül, Konya, 821-828.

FAO (2014). Statistical Databases, http://faostat.fao.org/site/567/default.aspx\#ancor, Son erişim tarihi: 3 Ağustos 2017.

Givens D I, Davies T W, Laverick R M (2000). Dietary fibre fractions in hulled and naked winter oat grain: effects of cultivar and various agronomic factors. Journal of the Science of Food and Agriculture, 80: 491- 496.

Kacar B (1994). Bitki ve Toprağın Kimyasal Analizleri. III. Toprak Analizleri. A.Ü.Z.F. Eğitim Araştırma ve Geliştirme Vakfı Yayınlar 1 No:3, s. 1-705, Ankara.

Kahraman T, Avcı R, Öztürk İ, Tülek A (2012). Trakya-Marmara Bölgesine uygun yulaf genotiplerinin belirlenmesi. Tarım Bilimleri Araştırma Dergisi, 5(2): 24-28.

Kara R, Dokuyucu T, Demirkıran A R, Dumlupınar Z, Akcura M, Akkaya A (2012). Groat element concentration at different spikelets of oat panicles (Avena sativa L.) evaluated at three Turkish locations. Turkish Journal of Field Crops, 17 (2): 157-165.

Kibite S, M J Edney (1998). The inheritance of $\beta$-glucan concentration in three oat (Avena sativa L.) crosses. Can. J. Plant Sci. 78:245-250.

Kliševičiūtė V, Švirmickas G J, , Alijošius S, Gružauskas R, Šašytė V, Racevičiūtė-Stupelienė A (2016). Nutritional value and digestible energy of different genotypes of oats in the horses nutrition. Veterinarija Ir Zootechnika (Vet Med Zoot). T. 73 (95) Supplement.

Kutlu H R (2008). Yem değerlendirme ve analiz yöntemleri. Çukurova Üniversitesi Ziraat Fakültesi Zootekni Bölümü. Ders notu. Z.M. 208. Adana.

Lipkovich İ, Smith E P (2002). Biplot and singular value decomposition macros for excel. Department of Statistics Virginia Tech Blacksburg, VA 24061-0439. http://www.jstatsoft.org/v07/i05/paper

Marshall A, Cowan S, Edwards S, Griffiths I, Howarth C, Langdon T, White E (2013).Crops that feed the world 9. Oats-a cereal crop for human and livestock feed with industrial applications. Food Security, 5 (1): 13-33.

Martinez M F, Arelovish H M, Wehrhahne L N (2010). Grain yield, nutrient content and lipid profile of oat genotypes grown in a semiarid environment. Field Crops Research, 116: 92-100.

McKechnie R (1983). Oat products in bakery foods. Cereal Foods World, 28(10): 635-637.

Mut Z, Erbaş Köse Ö D, Akay H (2016). Grain yield and some quality traits of different oat (Avena sativa L.) genotypes. International Journal of Environmental \& Agriculture Research. 2 (12):83-88.

Özcan M M, Özkan G, Topal A (2006). Characteristics of grains and oils of four different oats (Avena sativa L.) cultivars growing in Turkey. International Journal of Food Sciences and Nutrition, 57(56): 345-352. 
Peterson, DM, Wesenberg D M, Burrup D E, Erickson C A (2005). Relationships among agronomic traits and grain composition in oat genotypes grown in different environments. Crop Science, 45(4): 1249-1255.

Rodehutscord M, Rückert C, Maurer H P, Schenkel H, Schipprack W, Knudsen K E B, Schollenberger M, Laux M, Eklund M, Siegert W, Mosenthin R (2016). Variation in chemical composition and physical characteristics of cereal grains from different genotypes. Archives of Animal Nutrition, 70(2): 87-107.

Saastamoinen M, Kumpulainen J, Nummela S (1989). Genetic and environmental in oil content and fatty acid composition of oats, Cereal Chemistry, 66, 296-300.

Sabandüzen B, Akçura M (2017). Bazı yulaf genotiplerinin Çanakkale koşullarında verim ve verim unsurlarının incelenmesi. Türk Tarım ve Doğa Bilimleri Dergisi 4(2): 101-108.

Sarı N, İmamoğlu A, Pelit S, Yıldız Ö, Büyükkileci C (2016). Ege Bölgesi sahil kuşağına uygun yulaf (Avena sativa L.) genotiplerinin belirlenmesi. Tarla Bitkileri Merkez Araştırma Enstitüsü Dergisi, 25 (Özel say1-1): 158-164.

Sarı N, İmamoğlu A, Yıldız Ö (2012). Menemen ekolojik koşullarında bazı ümitvar yulaf hatlarının verim ve kalite özellikleri. Anadolu Ege Tarımsal Araştırma Enstitüsü Dergisi. 22 (1): 18-31.

SAS Institute Inc. (1990). SAS-procedures guide, version 6 (3rd ed.). Carry, USA.

Silva C F L, Milach S C K, Silva S D A, Montero C R (2008). Near infrared reflectance spectroscopy (NIRS) to assess protein and lipid contents in Avena sativa L. Crop Breed. Appl. Biotechnol. 8:127-133.

Stone P J, Savin R (1999). Wheat: Ecology and physiology of yield, determinant, food products pr inc (NY), New York, USA, 85-120 pp.

STN EN ISO 10520. (2002). Native starch. Determination of starch content. Ewers polarimetric method.

Tiwari U, Cummins E (2009). Simulation of the factors affecting ßeta-glucan levels during the cultivation of oats. Journal of Cereal Science, 1-9.

Tsikitis V L, Albina J E, Reichner J S (2004). Beta-glucan affects leukocyte navigation in a complex chemotactic gradient. Surgery, 136 (2): 384-9.

TÜİK (2016). Statistical Databases, http://www.tuik.gov.tr/VeriBilgi.do?alt_id=45, Son erişim tarihi: 3 Ağustos 2017.

Van Soest P J, Robertson J B, Lewis B A (1991). Methods for dietary fiber, neutral detergent fiber, and nonstarch polysaccharides in relation to animal nutrition. J. Dairy Sci., 74, 3583-3597.

Yan W, Frégeau-Reid J, Pageau D, Martin R (2016). Genotype-by-environment interaction and trait associations in two genetic populations of oat. Crop Sci. 56:1136-1145.

Yan W, Reid J F (2008). Breeding line selection based on multiple traits. Crop Sci (48): 417-423.

Yaver E, Ertaş N (2013). Yulafın bileşimi, hububat endüstrisinde kullanım alanları ve insan sağlı̆̆ı üzerine etkileri. Gıda ve Yem Bilimi - Teknolojisi Dergisi, 13:41-50.

Zhou M, Robards K, Glennie-Holmes M, Helliwell S (1999). Oat lipids: a review. Journal of the American Oil Chemists'Society, 79: 585-592. 